\title{
The Uneven History of Modern American Sexuality
}

\author{
Regina Kunzel
}

Modernity and sexuality are understood to go hand in hand-bound together in an overdetermined, co-constitutive relationship. Perhaps the most abiding narrative of modern sexuality, and of modernity more generally, is the story of the emergence of the notion of sexual identity and the formation and firming of a homo/heterosexual binary-the conviction that sexual desires, feelings, and actions signified sexual types: kinds of persons fundamentally defined by their sexual object choice. Indeed, the very notion of "sexuality" as a cornerstone of individual identity and selfhood is itself a modern production, created out of the confluence of modernity's distinctive forces. Late-nineteenth and early-twentieth-century scientific and medical theories identified and differentiated new sexual types, often linked to racial taxonomies. ${ }^{1}$ New freedoms and precarities ushered in by a capitalist economy, wage labor, and urbanization, and conditioned by global and continental migration, made novel sexual lifeways both newly possible and newly necessary. ${ }^{2}$ The rise of a modern bureaucratic state raised the stakes of sexual identification further, rewarding heterosexual settlement and targeting the homosexual as anti-citizen. ${ }^{3}$

The equation of modern sexuality with the invention of sexual identity was most famously articulated by Michel Foucault, who argued that the late nineteenth century witnessed a dramatic and consequential shift in the understanding of sex-one that bound sexual acts and desires to sexual identities. Increasingly, he proposed, medical and state authorities identified the homosexual as "a personage, a past, a case history, and a childhood, in addition to being a type of life, a life form, and a morphology, with an indiscreet anatomy and possibly a mysterious physiology." 4 Foucault's narrative has been challenged and complicated by historians since, many of whom identify ordinary people, often working-class people and immigrants, rather than sexologists and doctors, as the drivers of this epistemological transformation. But the prevailing notion that the history of modern sexuality is the history of the consolidation of sexual identities, hetero- and homosexual, has remained remarkably durable. As a result, we have a deep and rich body of historical work on how sexual identities have been forged, experienced, and understood, and how in turn they have led to collective identifications, community building, and political activism.

\footnotetext{
${ }^{1}$ Siobhan B. Somerville, Queering the Color Line: Race and the Invention of Homosexuality in American Culture (Durham, NC, 2000); Jennifer Terry, An American Obsession: Science, Medicine, and Homosexuality in Modern Society (Chicago, 1999); Julian B. Carter, The Heart of Whiteness: Normal Sexuality and Race in America, 1890-1940 (Durham, NC, 2007).

${ }^{2}$ John D'Emilio, "Capitalism and Gay Identity," in Powers of Desire: The Politics of Sexuality, eds. Ann Snitow, Christine Stansell, and Sharon Thompson (New York, 1983), 100-13; George Chauncey, Gay New York: Gender, Urban Culture, and the Making of the Gay Male World, 1890-1940 (New York, 1994); Nayan Shah, Stranger Intimacy: Contesting Race, Sexuality, and the Law in the North American West (Berkeley, 2012).

${ }^{3}$ See Margot Canaday, The Straight State: Sexuality and Citizenship in Twentieth-Century America (Princeton, NJ, 2009); Shah, Stranger Intimacy; Siobhan B. Somerville, "Notes Toward a Queer History of Naturalization," American Quarterly 57, no. 3 (Septmber 2005): 659-75; Lisa Duggan, The Twilight of Equality? Neoliberalism, Cultural Politics, and the Attack on Democracy (Boston, 2003); Peggy Pascoe, What Comes Naturally: Miscegenation Law and the Making of Race in America (New York, 2009).

${ }^{4}$ Michel Foucault, The History of Sexuality, Volume I: An Introduction, trans. Robert Hurley (New York, 1980), 43.

(c) The Author(s) 2018. Published by Cambridge University Press
} 
And yet this overarching story of sexual modernity risks becoming too totalizing. Region, class, and race complicate the history of what scholars sometimes term "sex as we know it" - shorthand for the presumed hegemony of a homo/heterosexual binary against which a less familiar sexual past is counterposed. Postcolonial scholars and anthropologists have noted the ways in which the narrative of sexual modernity has constrained our thinking about practices and ideas among non-Western and diasporic populations and, at the same time, has underwritten value-laden hierarchies of the purportedly pre-modern and modern. Anthropologist Martin F. Manalansan, for example, offers a powerful challenge to assumptions about the development of a uniform gay modernity in the late twentieth century in his ethnographic study of Filipino immigrants in New York City. ${ }^{5}$ Historians, too, have questioned whether sexual identity should be foregrounded in modern histories, and whether that focus on identity obscures other ways of making sense of sexual acts and desires. In his book on the postwar rural and small-town South, for example, John Howard finds that "gay identity in Mississippi (surely as elsewhere) existed alongside multiple queer desires that were not identity based or identity forging."

My own questions about the overarching narratives of modern sexual history led me to explore the shifting concerns, anxieties, and fascinations about sex in prison over the course of the nineteenth and twentieth centuries. Among my aims in Criminal Intimacy was to call attention to the incompleteness and unevenness of the modern sexual project, as well as the fretful labor involved in the making of modern sexuality and in propping up the belief in stable and fixed sexual identity. The history of sexuality looks different, I found, when sited in the prison: "Modern" sexuality appears less than fully arrived well into the twentieth century, heterosexuality appears less stable and more contingent, and alignments of non-normative gender and sexuality with racialization and criminalization are more visible. ${ }^{7}$ I was inspired in part by Eve Kosofsky Sedgwick's critique of what she gently derided as the "Great Paradigm Shift," and especially by her suggestion that the "topos of "homosexuality as we know it today" risks reinforcing "a dangerous consensus of knowingness about the genuinely unknown."

Histories of modern sexuality can be too sweeping in their characterization of the hegemony of the homo/heterosexual binary; they can also be overly celebratory, tracking a narrative of progress that smoothes out a rockier road. Modern sexuality was not uniform in its uptake or linear in its advance; neither was it universally or unambiguously welcomed as emancipatory or "true." Queer literary scholars, in particular, have proposed that while some surely embraced and helped elaborate new forms of sexual selfhood, not everyone easily abided by modern sexuality's identitarian demands. Attentive to the "negative, shameful, and difficult feelings that have been so central to queer existence in the last century," Heather Love looks to historical and literary figures who, when faced with modern sexuality, look backward. ${ }^{9}$ Peter Coviello considers the "curtailments, rather than the affordances, of the advent of modern sexuality" and speculates that to inhabit a sexuality "in the twilight moment before the arrival or calcifying of the terms of sexual identity ... might also be to enjoy a special kind of freedom." ${ }^{10}$ Some writers, activists, and artists, Scott Herring proposes, thwarted classificatory knowledge about sexuality and refused to comply with the modern obligation that homosexuality speak on its own behalf. ${ }^{11}$

\footnotetext{
${ }^{5}$ Martin F. Manalansan, Global Divas: Filipino Gay Men in the Diaspora (Durham, NC, 2003).

${ }^{6}$ John Howard, Men Like That: A Southern Queer History (Chicago, 1999).

${ }^{7}$ Regina Kunzel, Criminal Intimacy: Prison and the Uneven History of Modern American Sexuality (Chicago, 2008).

${ }^{8}$ Eve Kosofsky Sedgwick, Epistemology of the Closet (Berkeley, 1990), 44-45.

${ }^{9}$ Heather Love, Feeling Backward: Loss and the Politics of Queer History (Cambridge, MA, 2007), 127.

${ }^{10}$ Peter Coviello, Tomorrow's Parties: Sex and the Untimely in Nineteenth-Century America (New York, 2013), $11,7$.

${ }^{11}$ Scott Herring, Queering the Underworld: Slumming, Literature, and the Undoing of Lesbian and Gay History (Chicago, 2007).
} 
Among my larger goals in Criminal Intimacy was to show that sexual modernity, and the homo/heterosexual binary in particular, was not just a process of identity making, but also, and maybe even more so, was an ideological project (or set of projects) deeply enmeshed in larger social, political, and economic processes. In his agenda-setting 1983 article, "Capitalism and Gay Identity," John D'Emilio urged us to think along these lines. Often cited for his early and forceful argument for the historical construction of sexual identity, D'Emilio tracks the significance for sexuality in the transition from a household-based economy to a capitalist free labor economy that released sons (and to a lesser extent daughters) from obligations to the family. But in a passage that receives less attention, D'Emilio also alerts us to the contradictions attending that shift, noting the way in which the family took on "new significance as an affective unit, an institution that produced not goods but emotional satisfaction and happiness," even as it waned in economic importance. "The ideology of capitalist society," D'Emilio writes, "has enshrined the family as the source of love, affection, and emotional security, the place where our need for stable, intimate human relationships is satisfied." 12 That enshrinement of the family, alongside the destruction of its buttressing infrastructure, led to the hardening of heteronormativity and homophobia in the course of the twentieth century-a political project that ensured that the homo- and heterosexual binary did not simply describe different sexual identifications, but rather, constructed a rigid hierarchy-one that determined access to citizenship and belonging, to social provision, to equality under the law, to the assumption of full humanity.

Once we identify modern sexuality as an ideological production as much as an identitarian one, new and important questions come to the fore, questions that are beginning to be explored more fully. Here are just a few:

If, as George Chauncey argues, the homo/heterosexual binary is a "stunningly recent creation," how (and why) did it so quickly become naturalized as inevitable and part of our cultural common sense ${ }^{13}$ And how might we understand modern heterosexuality, the surprisingly understudied concept in that pairing, as itself a political project, one as fully historically constructed and contingent as homosexuality? ${ }^{14}$ Some works in gender history and LGBT/queer history offer profound insights into this question. For instance, Kathy Peiss charts the ways in which a newly heterosocial leisure culture at the turn of the twentieth century offered working-class women new sexual autonomy at the same time that it imposed new forms of vulnerability and sexual dependency, as self-fulfillment became linked more strongly to consumerism. Margot Canaday helps us see the processes by which heterosexuality became crucial to understandings of U.S. citizenship and central to its rewards and benefits. In her classic 1997 article, "Punks, Bulldaggers, and Welfare Queens," Cathy Cohen shows us how racialization has worked to stigmatize some expressions and manifestations of heterosexuality, making clear the importance of an intersectional analysis of modern American sexuality. ${ }^{15}$

Shifting the story of modern American sexuality from the consolidation of sexual identity to the consolidation of a heteronormative political project might also help us see more clearly the ways in which its benefits have been unequally distributed. Even as some former sexual outsiders have moved from what Gayle Rubin identified as the "outer limits" into the "charmed circle" of social acceptance and state recognition-folded into the national imaginary and bestowed with new benefits of citizenship —others remain subject to criminalization, stigmatization,

\footnotetext{
${ }^{12}$ D'Emilio, "Capitalism and Gay Identity," 103, 108.

${ }^{13}$ Chauncey, Gay New York, 13.

${ }^{14}$ See Jonathan Ned Katz, The Invention of Heterosexuality (Chicago, 1995); Kathy Peiss, Cheap Amusements: Working Women and Leisure in Turn-of-the-Century New York (Philadelphia, 1986).

${ }^{15}$ Peiss, Cheap Amusements; Canaday, The Straight State; Cathy J. Cohen, "Punks, Bulldaggers, and Welfare Queens: The Radical Potential of Queer Politics?” GLQ: A Journal of Lesbian and Gay Studies 3, no. 4 (May 1997): 437-65.
} 
and exclusion. ${ }^{16}$ For some, it does get better, as Dan Savage's feel-good YouTube project promised. At the same time, recent laws requiring people to use restrooms corresponding to their assigned-at-birth sex show the persistence of the association of queerness and predation, and especially with danger to children. Work by Sarah Haley, Talitha LeFlouria, Kali Gross, and Cheryl Hicks analyzes the enduring entanglement of sexual and racial exclusions and provides historical context to understand the continued hypervulnerability of queer and trans people of color to violence, criminalization, and incarceration. ${ }^{17}$

Finally, and perhaps most important, foregrounding questions of power and ideology in histories of modern sexuality might also help us understand what is often posed as a persistent undercurrent of anti-modernism in modern American history. As we witness the return of calls for "conversion therapy" for LGBT/queer and trans people and the rise of anti-LGBT rights and "religious freedom" bills in cities and states, it is tempting to view current events as evidence of "backlash"; at the very least, events of the early twenty-first century should cure us of any lingering illusions about the inevitability of a progressive march forward. A deeper sense of the complex history of competing sexual ideologies, and especially the coincidence of the durability of hetero- and gender normativity alongside advances in LGBT civil rights, cautions against viewing these developments as articulations of anti-modernism. Instead, they come into view as illiberal modernist trajectories that are themselves part of the story of modern American sexuality-ones that we neglect at the peril of our understanding the modern past and our own vexing present.

Regina Kunzel holds the Doris Stevens Chair and is Professor of History and Gender and Sexuality Studies at Princeton University. Her book Criminal Intimacy: Prison and the Uneven History of Modern American Sexuality (University of Chicago Press, 2008) was awarded the American Historical Association's John Boswell Prize, the MLA's Alan Bray Memorial Book Award, and the Lambda Literary Award for LGBT Studies. Kunzel is also the author of Fallen Women, Problem Girls: Unmarried Mothers and the Professionalization of Social Work, 1890 to 1945 (Yale University Press, 1993). She is working on a project exploring the encounter of LGBT/queer people with psychiatry in the twentieth-century U.S.

\footnotetext{
${ }^{16}$ Gayle Rubin, “Thinking Sex: Notes for a Radical Theory of the Politics of Sexuality," in Pleasure and Danger: Exploring Female Sexuality, ed. Carole S. Vance (Boston, 1984), 100-33.

${ }^{17}$ Sarah Haley, No Mercy Here: Gender, Punishment, and the Making of Jim Crow Modernity (Chapel Hill, NC, 2016); Talitha L. LeFlouria, Chained in Silence: Black Women and Convict Labor in the New South (Chapel Hill, NC, 2015); Kali N. Gross, Colored Amazons: Crime, Violence, and Black Women in the City of Brotherly Love, 18801910 (Durham, NC, 2006); Cheryl D. Hicks, Talk with You Like a Woman: African American Women, Justice, and Reform in New York, 1890-1935 (Chapel Hill, NC, 2010).
} 